\title{
Revised Research Design for Testing and Mitigation of Archaeological Resources Along Loop 1: North Extension of Mopac From US 183 to Just North of Parmer Lane
}

John W. Clark Jr.

Follow this and additional works at: https://scholarworks.sfasu.edu/ita

Part of the American Material Culture Commons, Archaeological Anthropology Commons, Environmental Studies Commons, Other American Studies Commons, Other Arts and Humanities Commons, Other History of Art, Architecture, and Archaeology Commons, and the United States History Commons

Tell us how this article helped you.

This Article is brought to you for free and open access by the Center for Regional Heritage Research at SFA ScholarWorks. It has been accepted for inclusion in Index of Texas Archaeology: Open Access Gray Literature from the Lone Star State by an authorized editor of SFA ScholarWorks. For more information, please contact cdsscholarworks@sfasu.edu. 


\section{Revised Research Design for Testing and Mitigation of Archaeological Resources Along Loop 1: North Extension of Mopac From US 183 to Just North of Parmer Lane}

\section{Licensing Statement}

This is a work produced for the Texas Department of Transportation (TxDOT) by the report producer. TxDOT and the report producer jointly own all rights, title, and interest in and to all intellectual property developed under TXDOT's contract with the report producer. The report may be cited and brief passages from this publication may be reproduced without permission provided that credit is given to both TxDOT and the report producer. Permission to reprint an entire chapter, section, figures or tables must be obtained in advance from either the Supervisor of the Archeological Studies Branch, Environmental Affairs Division, Texas Department of Transportation, 125 East 11th Street, Austin, Texas, 78701 or from the report producer. 
REVISESED

RESEARCH DESIGN FOR TESTING AND MITIGATION

OF ARCHAEOLOGICAL RESOURCES

ALONG LOOP 1: NORTH EXTENSION OF MOPAC

FROM US 183 TO JUST NORTH OF PARMER LANE

BY

John พ. Clark, Jr. 
INTRODUCTION

Archaeological sites within the right-of-way of the northward extension of Loop 1 (MoPac Boulevard), from US 183 to just north of Parmer Lane, are concentrated in two areas. One area is along an old road running north-south and lying to the west of the Balcones Research Center, and the other area is the late nineteenth century community of Waters Park.

The project involves the construction of a multilane divided freeway between the cited two termini. During initial reconnaissance in 1974, many sites were located within or near the proposed right-of-way. At that time and subsequently, site survey forms have been submitted to the Texas Archeological Research Laboratory, Balcones Research Center, The University of Texas at Austin; sites have been revisited and reevaluated; one site has been nominated to and is now listed on the National Register of Historic Places; one site has concurrently been determined eligible for listing on the Register; and one site complex (Waters Park) has been submitted for determination of eligibility to the National Register of Historic Places. A considerable amount of archival material was collected in 1974 and in the intervening years.

In accordance with Procedures for the Protection of Historic and Cultural Properties (36 CFR, Part 800), prescribed and endorsed by the Federal Highway Administration, and in concurrence with the office of the State Historic Preservation Officer, affected sites were evaluated with regard to their potential for eligibility for inclusion within the National Register of Historic Places. The sites likewise were evaluated for their suitability as state archaeological landmarks since they will be on state land once the right-of-way has been purchased and will fall under the aegis of the Texas Antiquities Code. 
The land on which the North Extension of Loop 1 is located formed parts of two land grants, one to James B. Rogers and one to James P. Wallace, dating to the Mexican Period (1811-1836). James B. Rogers came to Texas in 1831 and received two land grants, one of which was preempted for the permanent seat of government of the Republic of Texas, later to encompass the Capitol of the State of Texas, state government buildings, and the downtown portion of the City of Austin, and the other becoming the site for the Loop 1 North Extension. James P. Wallace came to Texas in 1835 and received two land grants at that time, one on a disputed section of land which was never patented to him and is not involved with Loop 1, and one which forms a portion of the Loop 1 North Extension.

When the first stages of the Texas Revolution commenced in late 1835, a Ranging Corps of the Western Frontier was organized. Both Wallace and Rogers became Rangers. Rogers, in addition to serving in the Rangers Corps, sold beef to the Texan army. Following the war, both men occupied the grants which later became the site for the Loop 1 North Extension of Mopac. Wallace, however, soon sold out to Rogers and received a grant of land adjacent to the Bastrop town tract as compensation for unpaid military claims and for wounds received while in service. Rogers remained on his land and Wallace became the clerk for the District Court of Bastrop County until his death in 1855.

Rogers sold off parcels of his land, mostly on the north end of his holdings. He died in 1860 and the remaining land was divided among his widow and children. One son and two sons-in-law served in the Confederate Army. In the next generation and in later generations descendants of James B. Rogers remained on the land, with two becoming county commissioners. Others served in the military during World War $\mathbf{I}$ and World War II. 
The Texas and New Orleans Railroad was constructed through the east side of the Rogers grant in 1871. A flag stop was established on property sold by Rogers to Silas B. Summers. In the 1880 s the line changed hands, becoming the Houston and Texas Central, and then becoming the Austin and Northwest Railroad. As the A\&NWRR, the line carried stone for the first Tom Miller Dam and for the present state capitol. The flag stop was upgraded with a station house and section house. In about 1890 a small village developed in the area of the railway station and originally was named Watters. A park was established which included a baseball field, dam and swimming pool, and gazebo. The greatest population of this small community was reached in 1910. This community became one of several localities near Austin which were popular for weekend excursions.

The community of Watters Park declined after 1910. Several structures were removed in the 1920s and others were destroyed by modern development in the 1970s and 1980s. Modern development on the Rogers and Wallace grants includes the construction of a magnesium plant for the Defense Department prior to World War II (this was later sold to The University of Texas, becoming the Balcones Research Center). More recent developments include a large plant for IBM, a business park, a variety of small businesses, housing developments, banks, a concrete yard, and other commercial endeavors. Little remains today of the original rural aspect of the land. 


\section{THE SITES}

Several sites are located in the right-of-way of the project. These sites will be described individually from south to north.

The James P. Wallace Site (Site 41TV291)

This site is bisected by an old abandoned north-south road. It lies partially in a clearing in juniper woods and consists of fallen limestone chimney stones, artifact concentrations, and areas where vegetation changes probably reflect the former location of a structure. The soil deposit throughout the site is a thin layer of Cenozoic clay over limestone bedrock. Artifacts located and collected during the 1974 survey include: blue edge-molded pearlware, spatter or spongeware, flown blue transfer print pearlware, Chinese porcelain, stoneware, bottle fragnents, wagon parts, and window glass.

Archival research indicates that this was the house site of James P. Wallace, an early Texas Ranger and Indian fighter. It was occupied for a short time from possibly before 1838, when Wallace patented his property, until about 1841 when he sold the tract to James B. Rogers.

The Rogers Spring Site (Site 41TV39)

The Rogers Spring Site consists of a multicomponent complex of Middle Archaic prehistoric burned rock middens, an early James B. Rogers house site, and a later James B. Rogers house site and associated outbuildings including two dams on the spring, a spring house, a smokehouse, and other features. The site is situated along the north side of the Rogers Spring with a heavy growth of oaks, watercress, and grasses along the bed of the spring, and oaks, junipers, and grasses away from the spring. 
Archaeological excavations at the site have been conducted on two occasions, first in 1933 by A. T. Jackson and again in 1974 by Elton R. Prewitt. Jackson entirely excavated three of five burned rock middens. Prewitt excavated a large part of a fourth midden and portions of the two house structure foundations. The fifth midden is well outside the right-of-way. Major portions of the fourth midden remaining after the Prewitt excavations have been vandalized.

Waters Park (Site 41TV286)

The community of Water Parks is located at the junction of $\mathbb{M} 1325$ with the Southern Pacific Railroad, adjacent to a bend in Walnut Creek. The site occupies both sides of the creek, both sides of the road, and both sides of the railroad. A heavy growth of oaks and cottonwoods is found along the creek, while areas away from the creek contain oaks and short grasses or are now entirely destroyed by development occurring since 1974. Soil deposits range from very shallow to as much as a meter deep adjacent to the creek.

At the request of the State Historic Preservation Office of the Texas Historical Commission, this site has been divided into its component parts with each part receiving a separate designation. Historically the site contained a trading store east of old $\mathbf{F} 1325$, the Mattie Bradfield house also east of old $\mathbb{F}$ 1325, a school between old $\mathbb{M} 1325$ and the railroad, a gin south of the school, a water tower south of the gin, a store and train stop west of the railroad, a baseball diamond southwest of the store between the road and the creek and west of the road, a dam and pool on the creek, a gazebo north of the creek, the Silas B. Summers house east of the road and south of the Bradfield house, the railroad section house at the crossing of the railroad and the old road, a tavern south of the station house, a dump east of the tavern, and the 
old bridge over Walnut Creek. The following features have now been destroyed and cannot be investigated archaeologically: the trading store, Bradfield house, school, gin, water tower, store and train stop, baseball field, and gazebo.

The Silas B. Summers House (S ite 41TV633)

This site consists of buried foundations overlain in part by a $1950 \mathrm{~s}$ frame house which was partially burned in the late 1960s. It is surrounded by oak trees and covered by lawn.

The Railroad Section House (Site 41TV632)

This site consists of a rectangular concrete slab which served as part of the structure's foundation. Adjacent to the structure are oak trees.

Waters Park Tavern (Site 41TV634)

No visible remains can be seen on the surface of this site. It lies south of the railroad section house and occupies a small clearing among a mott of oaks. The location of this site is based on the recollections of a resident reared and still living on the property.

Waters Park Dump (S ite 41TV635)

No visible remains of this site can be seen on the surface. It is southeast of the tavern location on a moderately steep slope of the bank of Walnut Creek. The location is based on informant recollections. The 
area has an upper canopy of oaks with small brush and a layer of leaf mold covering the deposits.

Waters Park Road (Site 41TV637)

Now known as $\mathbb{M}$ 1325, there are segments remaining of the original portions of this road which were bypassed and abandoned due to later modifications. The best preserved, unmodified segment of this old road is located east of modern $\mathbb{M} 1325$ where it crosses Walnut Creek. The area is now heavily wooded in part and grassed in other areas. The remains include the gravel road bed and adjacent ditches.

Waters Park Bridge (Site 41TV636)

Still in place over Walnut Creek is a small, cast-concrete bridge. Heavy oak and cottonwood growth is found adjacent to the structure. 


\section{SITES OUTSIDE THE RIGHT-OF-WAY}

A number of archaeological sites have been recorded near the right-ofway of this project. Most are historic and therefore have a relationship to the sites within the right-of-way. Indeed, all the sites discussed in relation to this project are within James P. Wallace's labor or James B. Rogers' league and are associated with later divisions of these grants.

Site $41 T V 297$

Little remains of this site other than scanty remnants of a springhouse, a concrete trough, and fence segments as recorded in 1974. The majority of the site was destroyed by the construction of present US 183 and clearing for construction of Loop 360 north of US 183. A 1937 aerial photo shows a house, barn, fences, and a pond.

\section{Site $41 T V 298$}

Since 1974, this site has been destroyed by removal of the house structure and dumping of tons of large limestone rocks over the site area. At that time the site was in a clearing within a juniper and oak woods and consisted of a house structure with portions of the sheathing removed and a pen. The 1937 aerial photo shows essentially the same situation .

Site 41TV299

When this site was surveyed in 1974 it had been largely destroyed for some time. Remains consisted of scattered artifacts, a small dump area, 
and a tract boundary fence. Artifacts collected at that time include a small number of cut and wire nails, transfer-printed ceramics, blueedged ceramics, and plain ceramics, modern tin cans, sheet metal, fragments of farm machinery, a stove top fragment, a spoon, and glass items including a soft drink bottle dated March 9, 1920. This site does not appear on the 1910 USGS Austin 30' quadrangle map, nor does it appear on the 1937 aerial photo. It seems likely that the site was constructed after 1910 and was destroyed before 1937.

Site $41 T V 292$

Remains of this site consist of chimney fall of the main house, an associated area of vegetation change marking the house position, a segment of the old north-south road, a vegetation change marking a barn or garage, and a segment of stone wall marking the yard. The soil deposit is thin to nonexistent over limestone bedrock. Junipers, oaks, and mesquites are common on the site. The 1937 aerial photo shows the house and barn or garage still standing. Artifacts collected or noted in 1974 include plain pearlware, stoneware, glass, wire nails, automobile parts of the 1930s, and sheet iron.

Site $41 T V 293$

This site is a burned store. Archaeological remains include stone foundation remnants, iron sign and stove parts, scattered glass, wire nails, crown bottle caps, a metal counter top, and corrugated tin roofing. Signs include a Dr. Pepper sign and a Coca Cola sign. In addition to the store structure is a dump and an area of vegetation change with occasional bricks and stones marking the location of an outbuilding-probably a shop, equipment shed, or some such structure. The soil 
deposit ranges from none to about $25 \mathrm{~cm}$ thickness. The store structure is present in the 1937 aerial photo.

\section{E. H. Rogers Homestead (S ite 41TV294)}

The E. H. Rogers Site consists of a stone masonry house, a two-log crib barn, and vegetational changes marking the locations of other out-buildings. The site is listed on the National Register of Historic Places. The quoins on the corners of the masonry house are carefully trimmed while the walls are coarse rubble with mud and rubble fill. The floor plan of the house is similar to a double-pen log house, with two rooms separated by a wide hall containing the front and rear doors. The two rooms open onto the central hall. The roof is corrugated galvanized sheet iron over wood shakes. Floor joists are local juniper, on juniper and rock piers.

Two cisterns are present at the site as are the remains of a windmill, water tank, and shed. Visible on the site are middle nineteenth century ceramics and glass. A plastered area on the rear of the house suggests the presence of a frame addition.

The Hardeman South Site (Site 41TV628)

The site consists of the post piers of a house which has been moved, a corral/shed complex, a shed, and a well. No artifacts were visible on the surface of the site. The site appears on the 1937 aerial photograph. Domestic vegetation marks the site and includes irises, ivy, and maguey. A trail runs north-south through the site. 
The Benjamin Gault House (Site 41TV296)

This house was removed sometime between 1980 and 1983 but was present in 1974 when the original survey was made. The house was a double-pen log house with central hall. It was sheathed with board-and-batten additions in the late nineteenth century. The house was built in 1855 on property inherited by Gault and his wife, Nancy L. Rogers, from James B. Rogers. The 1974 structure was an L-shaped board-and-batten house with a 1950s flat roof addition making a U-shaped structure.

The Hardeman North Site (Site 41TV629)

The site consists of an L-shaped, frame board-and-batten house with a tin roof. It was constructed late in the nineteenth century. It is present on the 1910 topographic map and the 1937 aerial photo. Associated with the house is a barn. The site is in the process of being destroyed by vandalism. Artifacts noted at the site include cut and wire nails, glass, and ceramics.

The Summers/Rinemer Site(Site 41TV283)

The site has been destroyed by housing development. In 1973, it consisted of the remains of a house foundation, the stone pier foundation of an outbuilding, a well, two pits, a latrine, and a stone yard fence. A minor test excavation was conducted at this site in 1973, encountering fragments of a cook stove, cinch buckles, mule shoes, barrel hoops, trace chain segments, cooking utensil fragments, food container fragments, cartridges, and nails. The principal occupation appears to be associated with Philip Rinemer at the turn of the century. This site appears on the 1910 topographic map. 
This is the site of the turn-of-the-century community of Duval. Site remains consist only of buried foundations. The site is endangered by development.

\section{Waters Park Dam (Site 41TV630)}

Lying across Walnut Creek at Waters Park is a simple concrete dam with a flat top, such that vehicles might pass over the dam from one side of the creek to the other. The structure was constructed in order to create a swimming pool, now washed out, for the resort area of Waters Park.

The Gazebo (Site 41TV631)

The gazebo foundations were destroyed in 1983 by a housing developer. The gazebo consisted of four stone piers approximately $2.5 \mathrm{ft}$. square and 2 to $3 \mathrm{ft}$. high. This structure was a base for the frame superstructure. It is present in the 1937 aerial photo.

Prehistoric Sites

A series of prehistoric sites lies outside the right-of-way. They include Sites 41TV98, 41TV287, 41TV288, 41TV113, 41TV114, 41TV518, and 41TV323. These are burned rock midden sites, except for site $41 \mathrm{TV} 323$ which is a lithic resource area. 
OBJECTIVES AND MEIHODS OF TESTING

In general, one can consider that the principal objectives of testing a site are:

1. To discover the depth of the deposits.

2. To probe the nature of artifacts to be encountered at the site.

3. To discover the nature of possible features.

4. To estimate the time range and cultural affiliation of the deposits.

5. To assess the potential for further information contained in the site.

The principal goal then is to determine the eligibility of the site for nomination to the National Register of Historic Places and ultimately whether the site will or will not be mitigated.

In the case of Site 41TV291, the James P. Wallace Site, it is felt that the objectives of testing are already known; that is, the depth of deposit, type of artifacts, features, time range, and cultural affiliation are already known and a concurrence determination of eligibility has been granted. Therefore, the site need not be tested but should be excavated. With Site 41TV633, the Silas B. Summers House, several of the testing objectives are also known. One that is not is the precise location of the major feature--the house. There is a later house apparently overlying a part of the original house site. The objective, then, in this instance, is to locate exactly on the ground the major feature of the site.

The major portion of Site 41TV632, the Railroad Section House, is located and the other testing objectives are known. It is believed that a portion of this site, however, is buried and testing here would be oriented to locating the buried portion of the site. The exact location of Site 41TV634, the Tavern, is not known and the objective here, 
likewise, is to precisely locate the major buried feature. Testing of Site 41TV635, the Waters Park Dump, again involves precise location of the major feature and measuring the horizontal extent of the feature. Objectives of testing Sites 41 TV636 and 41TV637, the Waters Park Bridge and the Old Road, are known; and therefore, testing is not felt to be profitable.

Thus, four sites are considered to be appropriate for testing while three are not. Since all sites to be tested are historic and were either constructed with iron nails or contain iron artifacts, it is believed that there is a simple method for defining the horizontal limits of the major features of these sites. It is proposed that a metal detector survey, with flagging and plotting of the hits, would define the sites. A site map with grid would be created showing the exact location of the features. Since all other objectives are known, this procedure would be sufficient to determine eligibility of the sites for inclusion within the National Register of Historic Places. 


\section{OBJECTIVES AND MEIHODS OF MITIGATION}

The objectives of mitigation are numerous because of the nature of the resources to be mitigated. When one is dealing with an historic site, one has a much wider range of cultural and historical data available than one would have with a prehistoric site. Therefore, the objectives are somewhat different than one would propose for a prehistoric site. The resources considered here consist of one early Anglo rural farmstead and a late nineteenth century resort and railroad community. Historic sources for these sites consist of a variety of documentation including deed and tax records, census data, military records, eye witness accounts of events in the area, railroad records, photographs, and more. The sites themselves contain discrete features, a variety of artifacts, and horizontal relationships that provide much cultural data.

Among the objectives of mitigation of the sites are the following:

1. To provide a chain of deed records of sales and purchases for the major properties involved.

2. To provide an historical background including as much biographical and genealogical information as possible.

3. To associate the sites with the early upper Anglo and Central Texas contemporary study units as defined in Brown et al. (1982).

4. To collect informant data on the cultural life at the Waters Park community.

5. To define spatial and cultural relationships for sites involved i $n$ the project area in relation to the old road running adjacent to the James P. Wallace and Rogers Spring Sites and to Waters Park.

6. To discuss the architecture of the sites.

7. To define the horizontal or spatial relationships within each site, compared to the other sites in the project and compared to 
sites in other areas where appropriate studies have been conductted.

8. To define patterns of artifact type frequencies for each site and compare the results to other sites.

9. To discuss the market system utilized by the site occupants with regard to artifact sources, both local and national.

10. To examine certain artifact categories with regard to their expression of relative wealth or status.

11. To discuss family and demographic patterns in relation to other areas of nineteenth century America.

12. To discuss subsistence as reflected by artifacts and organic materials at the sites.

In order to realize these objectives, a variety of methods will be utilized. At the present time a considerable amount of archival data has been collected including deed records, historical eye witness accounts, origins of settlers, informant data, and genealogical information. Pursuit of documentary or archival information will continue in order to provide adequate information to achieve objectives 1 through 5 . This will involve work at the Barker Texas History Center, State Archives, State Library, County Courthouse, Travis County Collection, interviews, visitation to the Rogers Hill Cemetery, and other efforts.

To achieve Objective 6, the features will be exposed, photographed, drawn, and compared to similar features still standing at other sites, visible in historic photographs, and otherwise documented, in order to develop as complete architectural reconstruction as possible. Objective 7 will be achieved through the gridding of the site and excavation or surface collection of the material. This procedure will be done via the establishment of grids (in the English measurement system, since this was the system used to construct the sites) and the passing of excavated material through 0.25 in. hardware cloth. The deposits are extremely 
shallow and not stratified, so, except in an unforeseen deep deposit, no vertical level increments will be utilized.

Objective 8 can be achieved by cataloging artifacts in preestablished categories (South 1977), quantifying them, and comparing them to artifact patterns defined in the existing literature. The actualization of Objective 9 involves the identification of place of manufacture of as many artifacts as possible. This procedure is relatively easy for ceramics and bottles. Many of these will represent national brands, while some will pertain to local distributors. Again, this information can be quantified and compared to other sites.

Objective 10 is likewise relatively easy to deal with. Certain kinds of ceramics, for example, are known to have been less expensive than others; the same is true with liquors, art glass, and other items in general use. The presence/absence of certain types of artifacts, as well as tax records, should provide the requisite data. There have been studies of family relationships and demography (Hareven and Vinovskis 1978) which will provide comparative data to which information generated by this project may be compared. Finally, subsistence evidence such as bottles, cans, and so forth, and actual food remains such as fruit pits, bones, egg shells, seafood shells, and so forth, will be studied. Bones can provide information on what animals were utilized, how they were cut, relative expense of cuts, and preferences of individual families, for example.

The objectives of mitigation herein listed have, as their common goal, the development of information on: the level of integration of the inhabitants of the area into national and local markets; material manifestations of ethnicity and social status; and horizontal patterning of artifacts and the functional pattern of artifacts as a manifestation of culture. Other goals include the development of a local history of the 
project area, encompassing land transactions, patterns of inheritance, family relationship patterns, demography of the area, and subsistence. 
PERSONNEL, DURATION, CURATION, REPORTING

The project director in charge of the field work and report writing will be John W. Clark, archaeologist for the Texas State Department of Highways and Public Transportation (SDHPT), Highway Design Division, Archaeology Section. Clark is a member of the Society of Professional Archeologists (SOPA) and is qualified in field research and historical archaeology, with extensive experience in a wide variety of historic sites, both as director of the excavation and as author of the final report. An effort will be made to employ George Nelson as assistant for the recording of features. Nelson has considerable artistic talent and has experience in the application of that talent to archaeological situations. Other crew members will be provided by the District 14 office of the SDHPT.

The duration of the project will be dependent on several factors, including crew size, weather, and unforeseen events or discoveries. It is estimated that a 11 excavation and recording will take two to three months, with an additional one to two months of archival research. The project will begin with mitigation of the James P. Wallace Site (Site 41TV291) and testing of the Waters Park sites, when purchase of the right-of-way is concluded and clearance from the Texas Historical Commission and Federal Highway Administration is provided. A request for determination of eligibility to the National Register of Historic Places for Waters Park has been sought. When this determination is provided, work will begin on the mitigation of those sites.

All cultural material recovered will be the property of the State of Texas. The State Department of Highways and Public Transportation will serve as a temporary repository for a 11 recovered materials as well as a 11 maps, photographs, field notes, and other written documentation generated through survey and testing until final disposition of these 
materials in a proper curational facility is determined. The report will be written in the most expeditious manner possible and will be printed in sufficient quantity to satisfy all requirements. As a part of the reporting procedures, the media will be notified of the project, and it is expected that the public will be aware of the project through newspaper and television coverage. 


\section{REFERENCES CITED}

Brown, Theodore M., Kay L. Killen, Helen Simons, and Virginia Wulfkuhle 1982 Resource Protection Planning Process for Tews. Texas Historical Commission, Austin.

Hareven, Tamora K., and Maris A. Vinovskis (Editors)

1978 Family and Population in Nineteenth-Century America. Princeton University Press, Princeton.

South, Stanley

1977 Method and Theory in Historical Archeology. Academic Press, New York. 